\title{
Использование сточных вод - экологическая безопасность Крыма
}

\author{
Н.М. Иванютин ${ }^{\bowtie}$, Н.Е. Волкова \\ ФГБУН «Научно исследовательский институт сельского хозяйства Крыма», \\ Российская Федерачия \\ (295493, г. Симферополь, ул. Киевская, 150)
}

\begin{abstract}
Аннотация: Цель - оценить объемы и качество очистки сточных вод с точки зрения целесообразности их использования для полива сельскохозяйственных культур.

Методы исследования. При выполнении исследований использовались общегеографические и общепринятые математические и статистические методы.

Обсуждение результатов. Исходя из анализа количественной составляющей формирующихся на территории Республики категории вод, наиболее перспективными источниками являются канализационные очистные сооружения (КОС) городов Симферополь, Ялта, Евпатория, Алушта, Феодосия, Керчь, Джанкой. На перспективу целесообразно рассмотреть возможность использования в качестве альтернативного источника поливной воды КОС Бахчисарая, Новоозерное («Донузлав»), Белогорска, объем формирующихся стоков которых составляет $0,5-1$ млн м³/год. Наилучшее по солевому составу качество имеют очищенные стоки городов Симферополь, Алушта, Судак, Белогорск (вода пригодна для целей орошения), наихудшее Евпатория, Керчь, Новоозерное («Донузлав»).

Заключение. Накапливать сточные воды следует в осенне-зимний период, по возможности используя для этого существующие пустые водоаккумулирующие сооружения, а затем использовать их в поливной сезон.
\end{abstract}

Ключевые слова: очищенные сточные воды, качество воды, орошение, загрязнение, экологическая безопасность.

Для цитирования: Иванютин Н.М., Волкова Н.Е. Использование сточных вод - экологическая безопасность Крыма // Вестник Воронежского государственного университета. Серия: География. Геоэкология, 2021, № 4, с. 69-76. DOI: https://doi.org/10.17308/geo.2021.4/3752

\section{ВВЕДЕНИЕ}

В Крыму ежегодно формируется более 100 млн м ${ }^{3}$ сточных вод различной степени очистки. При попадании в водоемы и водотоки они ухудшают качественные характеристики, сокращают количество чистых естественных водных ресурсов (поверхностных и подземных) и соответственно уменьшают рекреационный потенциал полуострова, снижая качество жизни населения.

В 2018 году объем сточных вод, сброшенных в водные объекты, составил около 160 млн м ${ }^{3}$, а в $2019-120$ млн м ${ }^{3} /$ год. Постепенно снижается процент нормативно очищенных стоков, что в первую очередь связано с износом фонда канализационно-очистных сооружений. Большинство сельских населенных пунктов полуострова не обустроено системами водоотведения. Фильтру- ющиеся из сливных и выгребных ям, фекальные стоки угрожают загрязнению водоемов.

Перекрытие украинцами Северо-Крымского канала заставило водохозяйственный комплекс Крыма переориентироваться на собственные водные ресурсы. Для удовлетворения питьевых нужд населения стали больше использовать подземные воды, осуществив ряд проектов по переброске части поверхностного стока в другие регионы полуострова. Одной из отраслей, где дефицит водных ресурсов ощущается наиболее остро, остается сельское хозяйство, которое ранее использовало почти 85 \% воды, поступавшей по каналу. Один из путей решения вопроса недостатка поверхностных и подземных вод для орошения - использование очищенных сточных вод городов и крупных населенных пунктов полуострова.

(C) Иванютин Н. М., Волкова Н.Е., 2021

$\triangle$ Иванютин Николай Михайлович, e-mail: redkolya@mail.ru Контент доступен под лицензией Creative Commons Attribution 4.0 License. 
Для понимания фактической ситуации необходимо иметь ввиду, что в 2019 году для орошения было применено всего 21,88 млн м ${ }^{3}$ водных ресурсов, а сброс очищенных стоков превысил данный объем в 5 раз. Главны- ми естественными приемниками сточных вод на полуострове Крым являются реки (Салгир, Биюк-Карасу, Чурук-Су), моря (Черное и Азовское), озера (Донузлав, Акташ) и пруды-накопители (рис. 1).

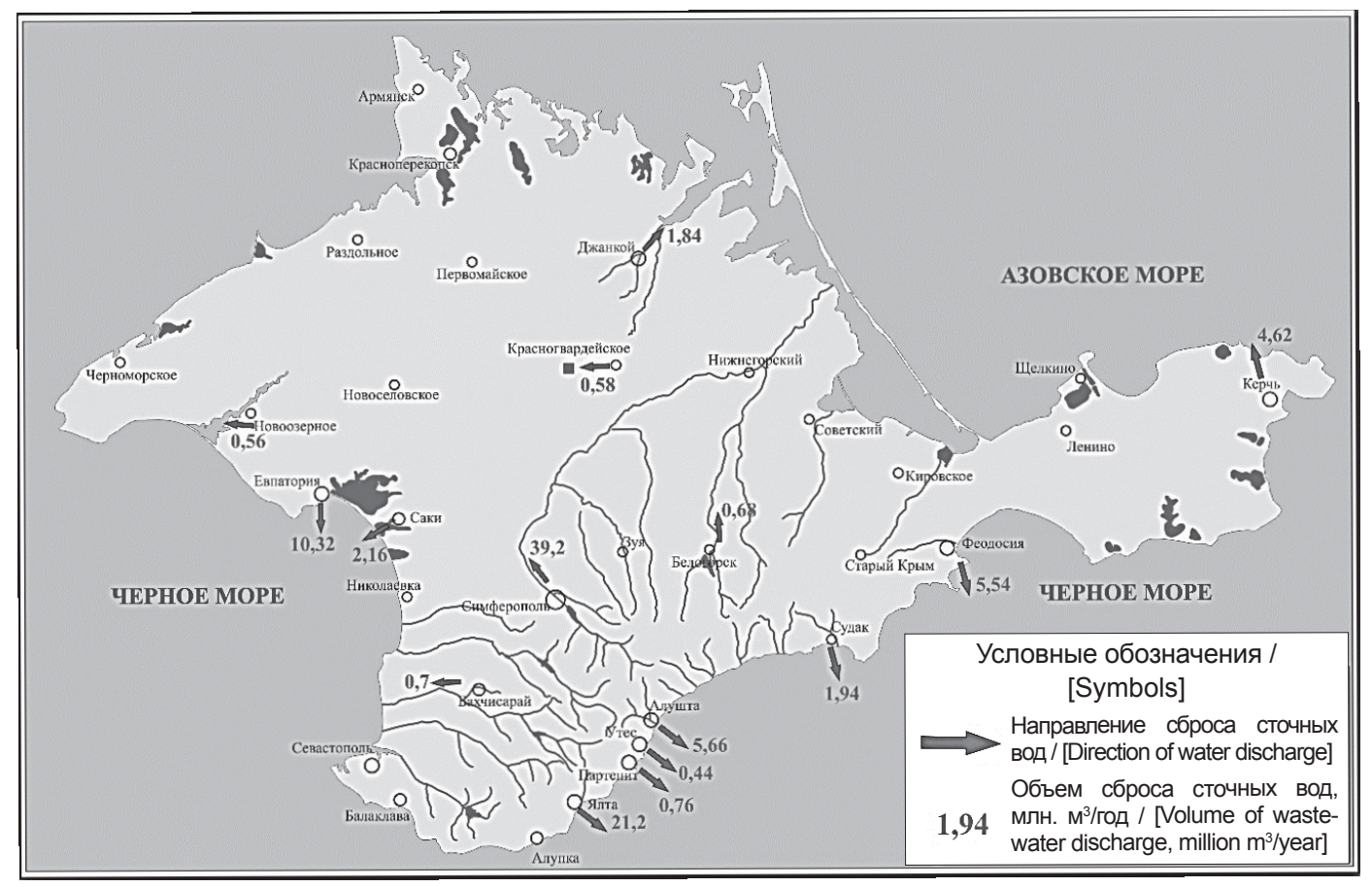

Puc. 1. Сброс очищенных сточных вод в водные объекты Крыма

[Fig. 1. Discharge of treated wastewater into water bodies in Crimea]

Повторное использование очищенных стоков это комплексная и очень сложная задача, решение которой позволит нам избавиться сразу от нескольких серьезных проблем, которые с каждым годом только усугубляются. Во-первых, повысится водообеспеченность сельскохозяйственной отрасли, в ней появятся новые рабочие места. Во-вторых, с экологической точки зрения уменьшится поступление загрязняющих веществ в природные водные объекты (особенно моря и озера), что также будет способствовать увеличению рекреационного потенциала Крыма. В-третьих, программа модернизации очистных сооружений привлечет дополнительные инвестиции в регион. В-четвертых, содержание органических веществ в сточных водах (азот, фосфор) будет способствовать обогащению почв питательными элементами.

Процесс внедрения орошения сточными водами в сельское хозяйство проходил в несколько этапов. Первые попытки использования сточных вод на полях орошения были предприняты в середине XIX века в Германии, Франции, США, Австралии, Южной Африке, Индии. В России первые поля орошения появились в Одессе (1887 г.),
Киеве (1892 г.), Москве (1898 г.). Дальнейшее ведение орошения сточными водами привело к выявлению различных проблем и необходимости решать новые задачи, которыми занимаются ученые с разных континентов.

В работах российских ученых $[8,11]$ большое внимание уделяется сохранению благоприятной экологической обстановки на орошаемом участке. Приоритет направлен на экологическую безопасность, а также вопросы влияния промышленных стоков на здоровье людей и окружающую среду $[3,12]$.

Немецкие и пакистанские ученые делают акцент на риски, связанные с химическим загрязнением выращиваемой продукции, с возможным попаданием в нее стойких органических соединений, антибиотиков [18] и тяжелых металлов [19, 20]. Исследователи из Африки (Марокко) [17] акцентируют внимание на необходимость повторного использования сточных вод своего региона для развития орошения и аквакультуры. Боливийцы (Южная Америка) отдают приоритет проведению постоянных микробиологических исследований участков орошения и выращиваемой сельскохо- 
зяйственной продукции [21]. Влияние сточных вод на почвенные условия представлены в работах египетских [15], греческих [22] и российских [9] исследователей. Немало работ посвящено вопросам влияния орошения сточными водами на подземные воды, что особенно актуально в засушливых регионах $[13,16]$.

В Крыму опыты по использованию очищенных сточных вод для орошения, показали возможность развития процессов засоления и осолонцевания почв, но в данных экспериментах использовались сточные воды с минерализацией 1,5-3 г/дм³ [2]. Общие вопросы и проблемы использования очищенных сточных вод, в том числе их пригодности для целей орошения, приведены в работах крымских ученых $[5,6,7,10]$.

\section{МЕТОДЫ ИССЛЕДОВАНИЯ}

Оценка возможности использования очищенных сточных вод в Крыму была проведена на основании анализа: 1) качественных показателей сточных вод, сбрасываемых с КОС полуострова в водные объекты; 2) количественных характеристик очищенных сточных вод, формирующихся на территории городов и крупных населенных пунктов.

Использована статистическая информация по форме 2ТП (водхоз), а также результаты наблюдений за качеством очистки сточных вод канализационных сооружений Республики Крым, проводимых специалистами ГУП РК «Вода Крыма».

Оценка пригодности водных ресурсов для целей орошения осуществлялась с использованием почвенно-мелиоративной классификации поливных вод [14].

\section{ОБСУЖДЕНИЕ РЕЗУЛЬТАТОВ}

Наглядным примером, подтверждающим, что экологическая безопасность водотоков Крыма снижается, является существенное ухудшение качества вод реки Салгир после сброса в нее стоков с очистных сооружений города Симферополя (рис. 2).

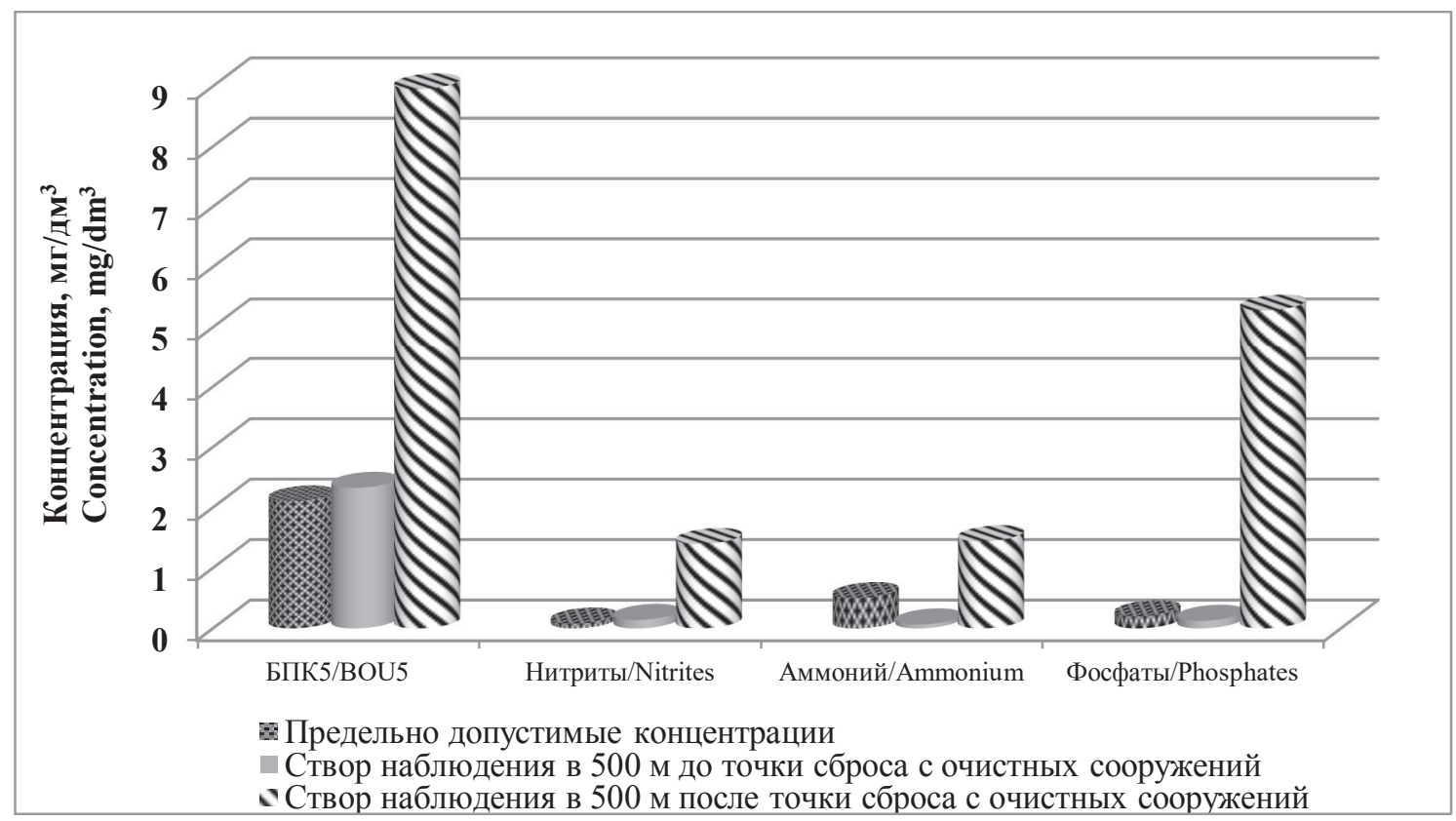

Puc. 2. Средняя концентрация загрязняющих веществ в водах р. Салгир до и после сброса очищенных сточных вод с КОС города Симферополя за 2019-2020 годы

[Fig. 2. Average concentration of pollutants in the Salgir River water before and after discharge of treated wastewater from the Simferopol sewage treatment facilities for 2019-2020]

Анализ рисунка 2 показывает, что после сброса стоков с очистных сооружений содержание БПК, нитритов, аммония и фосфатов в водах р. Салгир возросло, составив 4,$3 ; 17,4 ; 2,9 ; 26,4$ ПДК, соответственно.

К примеру, в среднем ежегодно со сточными водами в реку Салгир поступает около 3000 т сульфатов, 3000 т хлоридов, 20 т нитритов, 220 т нитратов,
13 т нефти и нефтепродуктов, 7 т СПАВ, 100 т фосфатов; в озеро Донузлав - по 200 т сульфатов и хлоридов, 18 т нитратов, 1 т нитритов, 40 т СПАВ, 3 т фосфатов. Расчет суммарного негативного влияния таких сбросов на растительные и животные сообщества, а также на человека затруднителен. Доказано, что сброс сточных вод в моря и лиманы снижает количество донной растительности, которая удержи- 
вает берега водоемов от размыва, а также сокращает количество моллюсков, створки которых служат для пополнения пляжного материала [4].

Для использования очищенных сточных вод на нужды сельского хозяйства необходимо: 1) проанализировать объемы стоков, возможных для изъятия; 2) провести оценку их качества; 3) проработать получение допуска на орошение стоками; 4) подобрать места аккумуляции стоков; 5) организовать подачу воды на поля; 6) запланировать научно-производственные и фитосанитарные работы на орошаемых участках.

Оценка количественного распределения очищенных сточных вод по региону показала, что наиболее перспективными альтернативными источниками данной категории воды на полуострове являются КОС городов Симферополь (39,19 млн м³/год), Ялта (21,2 млн м³/год), Евпато- рия (10,32 млн м³/год), Алушта (5,66 млн м³/год), Феодосия (5,54 млн м³/год), Керчь (4,62 млн м³ год), Саки (2,16 млн м³/год), Судак (1,94 млн м³/ год), Джанкой (1,84 млн м³/год). Необходимо рассматривать и менее крупные очистные сооружения с производительностью выше 500 тыс. м $^{3} /$ год, так как их воды хватит для орошения не менее 200 га сельскохозяйственных угодий. К таким объектам относятся КОС городов Бахчисарай $\left(0,7\right.$ млн. ${ }^{3} /$ год), Белогорск $\left(0,68\right.$ млн. м ${ }^{3} /$ год) и Новоозерное

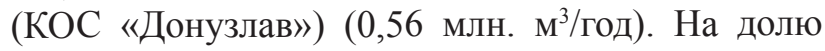
выше отмеченных очистных сооружений приходится около 80 \% объема сточных вод.

Использованию очищенных стоков по всем перспективным КОС Крыма мешает ряд проблем, среди которых основная - качество очищенных сточных вод, что сказывается на их пригодности для целей орошения (рис. 3).

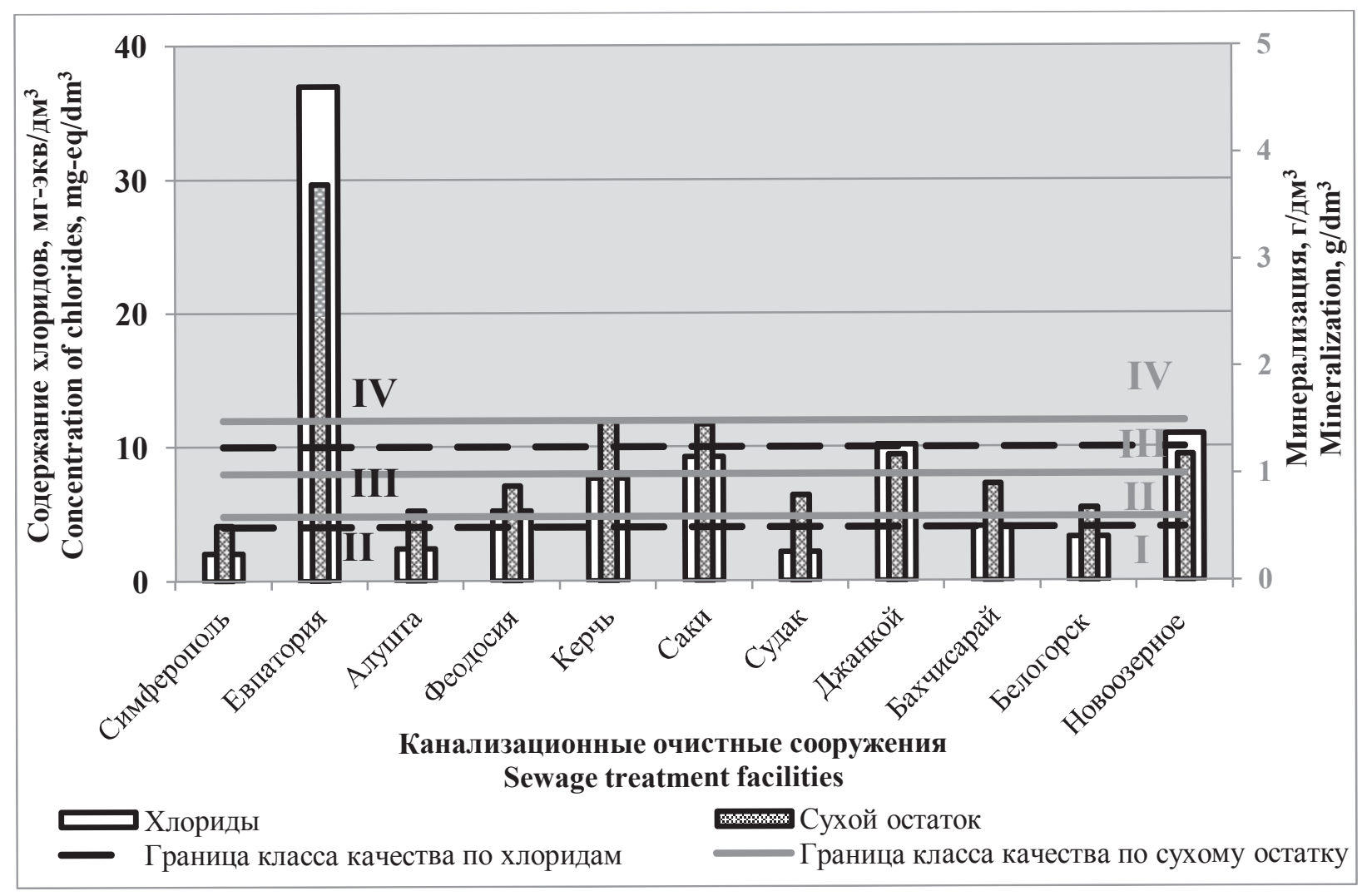

Puc. 3. Пригодность очищенных сточных вод Крыма для целей орошения по вероятности развития общего и хлоридного засоления

[Fig. 3. Suitability of treated wastewater in Crimea for irrigation purposes in terms of the likelihood of developing general and chloride salinity]

С точки зрения солевого состава очищенных стоков наиболее перспективными источниками воды для целей орошения являются канализационные сооружения городов Симферополь, Алушта, Судак, Бахчисарай, Белогорск. Наихуд- шие показатели были зафиксированы по КОС городов Евпатория, Саки, Керчь, Джанкой, Новоозерное («Донузлав») (IV класс - воду нецелесообразно использовать без предварительной водоподготовки). 
Сотрудниками научно-исследовательского института сельского хозяйства Крыма в период с 2016 по 2018 годы проводились опыты по изучению влияния орошения очищенными сточными водами КОС города Симферополь на почвенные условия, урожайность и качество сельскохозяйственных культур, в эксперимент были выбраны кормовая свекла и семенники сахарной свеклы российской селекции [1].

В результате проведенных исследований не было выявлено накопления тяжелых металлов в почве, не зафиксировано ухудшения мелиоративной обстановки. Содержание токсичных солей в почве за период исследования практически не изменилось, на конец проведения полевых опытов величина суммарного эффекта токсичных ионов составила 0,11 мг-экв $\mathrm{Cl}^{-} / 100$ г, то есть почва классифицируется как не засоленная. Кроме того полив очищенными стоками способствовал повышению урожайности выращиваемых культур. Данные опыты подтвердили целесообразность использования стоков очистных сооружений города Симферополя для целей орошения.

Стоит отметить, что очищенные сточные воды, поступающие с КОС формируют сток реки Салгир, воды которой еще на протяжении более 100 км используются населением, поэтому изымать весь объем сброса стоков недопустимо. Нормы возможного изъятия необходимо установить на основании водохозяйственных балансовых расчетов. Очищенные стоки можно накапливать в существующей системе прудов-накопителей в осенне-зимний период, когда на водные ресурсы реки наименьший спрос, к тому же они будут дополнительно проходить природную здесь доочистку (отстаивание, насыщение кислородом и т. д.). Затем их можно использоваться в весенне-летний цикл для орошения.

В Западном Крыму, после строительства очистных сооружений в пгт. Черноморское и реконструкции КОС Новоозерное, очищенные стоки можно было бы использовать для выращивания кормовых культур, необходимых для развития такой важной подотрасли животноводства как овцеводство.

Уменьшение сбросов сточных вод в природные водные объекты Западного Крыма (оз. Донузлав) позволит снизить антропогенную нагрузку, сохранить пляжи от размыва, а особо охраняемые природные территорий с множеством видов флоры и фауны, занесенные в Красные Книги РФ и Крыма от исчезновения. Такая перспектива открывает новые возможности для развития рекреационного комплекса, природоохранной деятельности и по- вышения экологической безопасности региона.

При дефиците водных ресурсов в Крыму использование очищенных сточных вод - это шаг не только к повышению экологической безопасности региона, сохранению уникальных природно-заповедных территорий, но и возможность получения дополнительного гарантированного источника водообеспечения сельскохозяйственной отрасли и путь к рациональному природопользованию.

Решение вопроса использования очищенных сточных вод для нужд сельского хозяйства требует создание управленческой структуры, в которую вошли бы представители регионального правительства, профильных министерств, науки, предпринимателей и общественности. Такой симбиоз позволит разработать комплексную, научно-обоснованную программу для рационального использования ресурсов Крыма.

\section{ЗАКЛЮЧЕНИЕ}

В ходе исследований были сделаны следующие выводы.

1. Крупные КОС Республики Крым - перспективные альтернативные источники воды для повышения водообеспеченности сельскохозяйственной отрасли.

2. Основной фактор, сдерживающий возможность использования сточных вод для целей орошения в Крымском регионе - качество очищенных сточных вод.

3. С точки зрения качественных и количественных характеристик сточных вод наиболее перспективными источниками для водообеспечения сельскохозяйственной отрасли Республики являются КОС городов Симферополь, Алушта, Судак, Бахчисарай, Белогорск.

4. Результаты опытов по оценке влияния использования очищенных сточных вод КОС города Симферополь для полива кормовой свеклы и семенников сахарной свеклы показали, что на орошаемом участке не было зафиксировано развитие неблагоприятных почвенных процессов, качество полученной продукции соответствовало ГОСТам РФ.

5. При обосновании возможности использования очищенных сточных вод в Республике Крым целесообразно учесть не только их качественные и количественные характеристики, но и проработать вопросы, связанные с местом расположения перспективных участков орошения, возможностями их накопления в пустующих аккумулирующих сооружениях, влиянием сбросов на формирование речного стока, организацией мониторинговых наблюдений за составом вод, изменением почвенных условий. 


\section{СПИСОК ЛИТЕРАТУРЫ}

1. Боровой Е.П., Ходяков Е.А., Кременской В.И., Джапарова А.М. Перспектива выращивания свеклы при поливе очищенной сточной водой в Крыму // Известия Нижневолжского агроуниверситетского комплекса: Наука и высшее профессиональное образование, 2018, №3 (51), с. 145-152.

2. Волкова Н. Е., Захаров Р. Ю. Использование очищенных сточных вод в Крыму: опыт прошлого, реалии настоящего // Научный журнал Российского НИИ проблем мелиоращии, 2017, № 3 (27), с. 144-159.

3. Герасимов А.С., Мельников А.А. Нормативное содержание нефтепродуктов и фенолов в сточных водах очистных сооружений Северной железной дороги // Вестник Воронежского государственного университета. Серия: География. Геоэкология, 2019, № 2, c. 73-76. DOI: https://doi.org/10.17308/geo.2019.2/2305

4. Горячкин Ю.Н., Долотов В.В. Морские берега Крыма. Севастополь: ООО «КОЛОРИТ», 2019. 256 с.

5. Захаров Р.Ю., Волкова Н.Е. Динамика качественных показателей очищенных сточных вод в крымском регионе // Строительство и техногенная безопасность, 2017, № 7 (59), с. 141-145.

6. Иванютин Н. М., Подовалова С. В. Загрязнение водных объектов Крыма сточными водами // Экология $и$ строительство, 2018, № 1, с. 4-8. DOI: 10.24411/24138452-2018-00001

7. Иванютин Н. М., Подовалова С. В. Оценка минерального состава и токсичности очищенных сточных вод Крыма как альтернативного источника воды для орошения // Таврический вестник аграрной науки, 2018, № 1 (13), c. 53-64. DOI: 10.25637/TVAN2018.01.04

8. Имангазинова Ж.С., Мукашева Д.М., Джетимов М.А. Использование сточных вод в производстве кормовых культур // Естественные и математические науки в современном мире, 2015, № 36-37, с. 207-217.

9. Копытовский В. В. Влияние длительного орошения животноводческими стоками на свойства почвы // Мелиорация, 2014, № 1 (71), с. 45-52.

10. Ляшевский В.И., Вердыш М.В., Кременской В.И. Изучение возможностей использования очищенных сточных вод для орошения в Крыму // Таврический вестник аграрной науки, 2016, № 4 (8), с. 121-129.

11. Макарычев С. В., Алешина Н.И. Экологические особенности орошения многолетних трав городскими сточными водами // Вестник Алтайского государственного аграрного университета, 2015, № 9 (131), с. 53-57.

12. Никольская А.Н., Маркин А.И. Экологическая оценка влияния предприятия пищевой отрасли промышленности на химическое загрязнение окружающей среды // Вестник Воронежского государственного университета. Серия: География. Геоэкология, 2016, № 1, c. 60-62.

13. Семененко А.С. Влияние орошения животноводческими стоками на подземные воды // Mатериаль на- учно-практической конференичи «Научное обоснование национального проекта «Развитие АПК», 2008, с. 65-67.

14. Шумаков Б. Б. Мелиорация и водное хозяйство. T. 6. Орошение: справочник. М.: Агропромиздат, 1990. $415 \mathrm{c}$.

15. Abd-Elwahed M. S. Effect of long-term wastewater irrigation on the quality of alluvial soil for agricultural sustainability // Annals of Agricultural Sciences, Volume 64, Issue 2, December 2019, pp. 151-160. DOI: 10.1016/j. aoas.2019.10.003

16. Bemmoussat A., Adjim M., Bensaoula F. Irrigation with treated wastewaters and the protection of Hennaya groundwater-Tlemcen, Algeria // Journal of Water and Land Development, Volume 43, Issue 1, 1 December 2019, pp. 19-27. DOI: $10.2478 /$ jwld-2019-0059

17. Faouzi E., Arioua A., Karaoui I., Ait Ouhamchich K., Elhamdouni D. Wastewater reuse in agriculture sector: Resources management and adaptation in the context of climate change: Case study of the Beni Mellal-Khenifra region, Morocco // E3S Web of Conferences, 2020, Volume 183, № 020052020. DOI: 10.1051/e3sconf/202018302005

18. Helmecke M., Fries E., Schulte C. Regulating water reuse for agricultural irrigation: risks related to organic micro-contaminants // Environmental Sciences Europe, Volume 32, Issue 1, 1 December 2020, № 4. DOI: 10.1186/ s12302-019-0283-0

19. Khan Z.I., Malik I.S., Ma J., Chen F., Yang Y., Ahmad K., Wajid K., Bashir H., Nadeem M., Ashfaq A., Munir M., Ugulu I., Dogan Y. Assessment of cadmium in maize and millet of different district using canal and wastewater irrigation // Revista de Chimie, 2020, Volume 71, Issue 7, pp. 406-418. DOI: 10.37358/RC.20.7.8258

20. Mahfooz Y., Yasar A., Guijian L., Islam Q.U., Akhtar A. B. T., Rasheed R., Irshad S., Naeem U. Critical risk analysis of metals toxicity in wastewater irrigated soil and crops: a study of a semi-arid developing region // Scientific Reports, Volume 10, Issue 1, 1 December 2020, № 12845. DOI: 10.1038/s41598-020-69815-0

21. Perez-Mercado L.F., Lalander C., Joel A., Ottoson J., Iriarte M., Oporto C., Vinneräs B. Pathogens in crop production systems irrigated with low-quality water in Bolivia // Journal of Water and Health, Volume 16, Issue 6, December 2018, pp. 980-990. DOI: 10.2166/wh.2018.079

22. Tsigoida A., Argyrokastritis I. The effect of subirrigation with untreated and treated municipal wastewater on organic matter and nitrogen content in two different soils // Global Nest Journal, Volume 21, Issue 3, December 2019, pp. 389-398. DOI: 10.30955/gnj.002810

Конфликт интересов: Авторы декларируют отсутствие явных и потенциальных конфликтов интересов, связанных с публикацией настоящей статьи.

Поступила в редакцию 21.04.2021 Принята к публикации 23.11.2021 


\title{
Waste Water Use - the Environmental Safety of Crimea
}

\author{
N. M. Ivanyutin $\bowtie$, N.E.Volkova \\ Research Institute of Agriculture of Crimea, Russian Federation \\ (150, Kievskaya Str., Simferopol, 295493)
}

\begin{abstract}
The purpose is to assess the volume and quality of wastewater treatment in terms of the feasibility of using it to irrigate crops.

Methods. General geographical and generally accepted mathematical and statistical methods were used in the research.

Results and discussion. On the basis of the analysis of the quantitative component of the waters formed in the territory of the Republic of Crimea, the most promising sources are sewage treatment facilities of the cities of Simferopol, Yalta, Evpatoria, Alushta, Feodosia, Kerch, Dzhankoy. For the future, it is advisable to consider using the sewage treatment facilities of Bakhchisaray, Novoozernoye ("Donuzlav") and Belogorsk as an alternative source of irrigation water, with the volume of generated wastewater being $0.5-1$ million $\mathrm{m} 3 /$ year. The best salt quality is found in treated wastewater from the towns of Simferopol, Alushta, Sudak and Belogorsk (water suitable for irrigation purposes), while the worst is in Yevpatoria, Kerch and Novoozernoye ("Donuzlav"). Wastewater should be stored in the autumn-winter period, if possible using existing empty water storage facilities, and then used in the irrigation season.
\end{abstract}

Key words: treated wastewater, water quality, irrigation, pollution, environmental safety.

For citation: Ivanyutin N. M., Volkova N.E Waste Water Use - the Environmental Safety of Crimea. Vestnik Voronezskogo gosudarstvennogo universiteta. Seria: Geografia. Geoekologia, 2021, no. 4, pp. 69-76. (In Russ.) DOI: https://doi.org/10.17308/geo.2021.4/3752

\section{REFERENCES}

1. Borovoj E.P., Hodyakov E.A., Kremenskoj V.I., Dzhaparova A.M. Perspektiva vyrashchivaniya svekly pri polive ochishchennoj stochnoj vodoj v Krymu [Perspective of the growing of the beet under irrigation by purified wastewater in Crimea]. Izvestiya Nizhnevolzhskogo agrouniversitetskogo kompleksa: Nauka i vysshee professional'noe obrazovanie, 2018, no. 3 (51), pp. 145-152. (In Russ.)

2. Volkova N.E., Zaharov R. Yu. Ispol'zovanie ochishchennyh stochnyh vod v Krymu: opyt proshlogo, realii nastoyashchego [Treated sewage waters usage in Crimea: experience of the past, reality of the present]. Nauchnyj zhurnal Rossijskogo NII problem melioracii, 2017, no. 3 (27), pp. 144-159. (In Russ.)

3. Gerasimov A. S., Melnikov A.A. Normative content of oil products and phenols in wastewaters of the Northern railway treatment facilities // Vestnik Voronezskogo gosudarstvennogo universiteta. Seria: Geografia. Geoekologia, 2019, no. 2, pp. 73-76. (In Russ.) DOI: https://doi. org/10.17308/geo.2019.2/2305

4. Goryachkin Yu. N., Dolotov V.V. Morskie berega Kryma [Sea coast of Crimea]. Sevastopol': OOO «KOLORIT», 2019. 256 p. (In Russ.)
5. Zaharov R. Yu., Volkova N.E. Dinamika kachestvennyh pokazatelej ochishchennyh stochnyh vod v krymskom regione [Dynamics of quality indicators of the purified sewage in the Crimean region]. Stroitel'stvo i tekhnogennaya bezopasnost', 2017, no. 7 (59), pp. 141-145. (In Russ.)

6. Ivanyutin N.M., Podovalova S.V. Zagryaznenie vodnyh ob"ektov Kryma stochnymi vodami [The pollution of water bodies in the Crimea by wastewater]. Ekologiya i stroitel'stvo, 2018, no. 1, pp. 4-8. (In Russ.) DOI: $10.24411 / 2413-8452-2018-00001$

7. Ivanyutin N.M., Podovalova S.V. Ocenka mineral'nogo sostava i toksichnosti ochishchennyh stochnyh vod Kryma kak al'ternativnogo istochnika vody dlya orosheniya [Evaluation of mineral composition and toxicity of treated wastewater in the Crimea as alternative water source for irrigation]. Tavricheskij vestnik agrarnoj nauki, 2018, no. 1 (13), pp. 53-64. (In Russ.) DOI: 10.25637/ TVAN2018.01.04

8. Imangazinova Zh.S., Mukasheva D.M., Dzhetimov M.A. Ispol'zovanie stochnyh vod v proizvodstve kormovyh kul'tur [The use of wastewater in the production of fodder crops]. Estestvennye i matematicheskie nauki $v$ sovremennom mire, 2015, no. 36-37, pp. 207-217.

\footnotetext{
(C) Ivanyutin N.M., Volkova N.E., 2021

$\varangle$ Nikolay M. Ivanyutin, e-mail: redkolya@mail.ru
}

The content is available under Creative Commons Attribution 4.0 License. 
9. Kopytovskij V.V. Vliyanie dlitel'nogo orosheniya zhivotnovodcheskimi stokami na svojstva pochvy [Influence of the long irrigation by livestock drains on properties of the soil]. Melioraciya, 2014, no. 1 (71), pp. 45-52. (In Russ.)

10. Lyashevskij V. I., Verdysh M. V., Kremenskoj V. I. Izuchenie vozmozhnostej ispol'zovaniya ochishchennyh stochnyh vod dlya orosheniya $\mathrm{v}$ Krymu [Studying of opportunites of the treated wastewater using for irrigation in Crimea]. Tavricheskij vestnik agrarnoj nauki, 2016, no. 4 (8), pp. 121-129. (In Russ.)

11. Makarychev S.V., Aleshina N.I. Ekologicheskie osobennosti orosheniya mnogoletnih trav gorodskimi stochnymi vodami [Environmental aspects of irrigating perennial grasses with urban sewage water]. Vestnik Altajskogo gosudarstvennogo agrarnogo universiteta, 2015, no. 9 (131), pp. 53-57. (In Russ.)

12. Nikol'skaya A.N., Markin Al.I. Jekologicheskaja ocenka vlijanija predprijatija pishhevoj otrasli promyshlennosti na himicheskoe zagrjaznenie okruzhajushhej sredy [Ecological estimation of the effect of food industry enterprises on chemical pollution of the environment]. Vestnik Voronezskogo gosudarstvennogo universiteta. Seria: Geografia. Geoekologia, 2016, no. 1, pp. 60-62. (In Russ.)

13. Semenenko A.S. Vliyanie orosheniya zhivotnovodcheskimi stokami na podzemnye vody [Impact of livestock runoff irrigation on groundwater]. Materialy nauchno-prakticheskoj konferencii «Nauchnoe obosnovanie nacional'nogo proekta «Razvitie APK», 2008, pp. 65-67. (In Russ.)

14. Shumakov B. B. Melioraciya i vodnoe hozyajstvo. T. 6. Oroshenie: spravochnik. [Land reclamation and water management. Vol. 6. Irrigation: handbook]. M.: Agropromizdat, 1990. 415 p. (In Russ.)

15. Abd-Elwahed M.S. Effect of long-term wastewater irrigation on the quality of alluvial soil for agricultural sustainability. Annals of Agricultural Sciences, Volume 64, Issue 2, December 2019, pp. 151-160. DOI: 10.1016/j. aoas.2019.10.003

16. Bemmoussat A., Adjim M., Bensaoula F. Irrigation with treated wastewaters and the protection of Hennaya groundwater-Tlemcen, Algeria. Journal of Water and Land

\section{Иванютин Николай Михайлович}

младший научный сотрудник ФГБУН «НИИСХ Крымa», г. Симферополь, Российская Федерация, ORCID: 0000-0001-8009-3857, e-mail: redkolya@mail.ru

Волкова Наталия Евгеньевна

старший научный сотрудник ФГБУН «НИИСХ Крыма», г. Симферополь, Российская Федерация, ORCID: 0000-0002-3146-652X, e-mail: volkova_n@niishk.ru
Development, Volume 43, Issue 1, 1 December 2019, pp. 19-27. DOI: 10.2478/jwld-2019-0059

17. Faouzi E., Arioua A., Karaoui I., Ait Ouhamchich K., Elhamdouni D. Wastewater reuse in agriculture sector: Resources management and adaptation in the context of climate change: Case study of the Beni Mellal-Khenifra region, Morocco. E3S Web of Conferences, 2020, Volume 183, № 020052020. DOI: 10.1051/e3sconf/202018302005

18. Helmecke M., Fries E., Schulte C. Regulating water reuse for agricultural irrigation: risks related to organic micro-contaminants. Environmental Sciences Europe, Volume 32, Issue 1, 1 December 2020, № 4. DOI: 10.1186/ s12302-019-0283-0

19. Khan Z.I., Malik I. S., Ma J., Chen F., Yang Y., Ahmad K., Wajid K., Bashir H., Nadeem M., Ashfaq A., Munir M., Ugulu I., Dogan Y. Assessment of cadmium in maize and millet of different district using canal and wastewater irrigation. Revista de Chimie, 2020, Volume 71, Issue 7, pp. 406-418. DOI: 10.37358/RC.20.7.8258

20. Mahfooz Y., Yasar A., Guijian L., Islam Q.U., Akhtar A.B.T., Rasheed, R., Irshad S., Naeem U. Critical risk analysis of metals toxicity in wastewater irrigated soil and crops: a study of a semi-arid developing region. Scientific Reports, Volume 10, Issue 1, 1 December 2020, № 12845. DOI: 10.1038/s41598-020-69815-0

21. Perez-Mercado L.F., Lalander C., Joel A., Ottoson J., Iriarte M., Oporto C., Vinneräs B. Pathogens in crop production systems irrigated with low-quality water in Bolivia. Journal of Water and Health, Volume 16, Issue 6, December 2018, pp. 980-990. DOI: 10.2166/wh.2018.079

22. Tsigoida A., Argyrokastritis I. The effect of sub-irrigation with untreated and treated municipal wastewater on organic matter and nitrogen content in two different soils. Global Nest Journal, Volume 21, Issue 3, December 2019, pp. 389-398. DOI: $10.30955 /$ gnj.002810

Conflict of interests: The authors declare no information of obvious and potential conflicts of interest related to the publication of this article.

Received: 21.04.2021

Accepted: 23.11.2021

Nikolay M. Ivanyutin

Junior Researcher of the Research Institute of Agriculture of Crimea, Simferopol, Russian Federation, ORCID: 00000001-8009-3857, e-mail: redkolya@mail.ru

Nataliya E. Volkova

Senior Researcher of the Research Institute of Agriculture of Crimea, Simferopol, Russian Federation, ORCID: 00000002-3146-652X, e-mail: volkova_n@niishk.ru 